\title{
Causal Relationship between Domestic Saving and Economic Growth: Evidence from Cambodia
}

\author{
Seng Sothan ${ }^{1}$ \\ ${ }^{1}$ College of Business Management, Life University, Sihanoukville, Cambodia \\ Correspondence: Seng Sothan, College of Business Management, Life University, Sihanoukville, Cambodia. \\ E-mail: sothans@yahoo.com
}

Received: June 8, 2014

Accepted: June 22, 2014

Online Published: August 25, 2014

doi:10.5539/ijef.v6n9p213

URL: http://dx.doi.org/10.5539/ijef.v6n9p213

\begin{abstract}
The present study attempts to determine the direction of causality between domestic saving and economic growth in Cambodia, using data for the period 1989-2012. The empirical analysis was based on Granger Causality Test. The study found that domestic saving does not Granger cause economic growth. This finding is contrary to the conventional wisdom that causality runs from saving to economic growth. Economic growth itself is also not found to Granger cause saving. So it can be concluded that domestic saving and economic growth are independent of each other in Cambodia.
\end{abstract}

Keywords: Cambodia, causality, domestic saving, economic growth, GDP

\section{Introduction}

The impact of saving on economic growth has caught international attention among researchers and policy makers from both developed and developing countries. In the neoclassical growth model led by Robert Solow (1956) reveals a clear connection between saving and economic growth. The model indicates that higher saving leads to higher investment, which in turn leads to higher economic growth. The presupposition is that higher saving contributes positively to economic growth; therefore, this has led to strong macroeconomic policy recommendations for development in many countries.

Although saving is found to have positive impact on economic growth as postulated in the conventional growth model of Solow (1956), it is not known whether the variable has impact on Cambodian economic growth. Cambodia, a country located in Southeast Asia and also a member of the Association of Southeast Asian Nations (ASEAN), had passed through many tragic generations, particularly the Pol Pot regime ${ }^{1}$, which destroyed the lives of millions of people and almost all types of infrastructure. In addition, the country's financial sector was extremely devastated. The national currency, Riel, was banned and banks were closed. Fortunately, after the Pol Pot regime was toppled in 1979 and the first UN-supervised general election ${ }^{2}$ in 1993, the financial sector in Cambodia is likely to reemerge and banks are motivated to reopen. Although the Cambodian financial sector seems to reemerge, it is still at the early stages of development. It just fully started in the early 1990s after the government launched the economic reform program from a planned economy to a market economy. This indicates that the development of the financial sector in Cambodia has a very short-time period. After the adoption of the Law on Banking and Financial Institutions in November 1999, the number of commercial banks and microfinance institutions started to increase. Since then domestic saving has also increased to a desirable level although it is not as high as that of other member states of ASEAN. Internationally, there have been a lot of theoretical and empirical studies on the role of financial development, specifically saving, in stimulating economic growth across countries. Most of the studies confirm a positive contribution of saving to economic growth (Harrod, 1039; Solow, 1956; Oladipo, 2010; Romm, 2005; Jappelli \& Pagano, 1994; Aghion, Comin, Howitt, \& Tecu, 2009) while others found reverse causality, which is contrary to the conventional wisdom that causality runs from saving to economic growth (Sinha \& Sinha, 1998; Sinha \& Sinha, 2008; Abu, 2010; Ijeoma, Paramaiah, \& Moshoeshoe, 2011). The empirical findings seem to be inconclusive. Aside from this, it is not known whether saving plays a major role in explaining economic growth in Cambodia as postulated in the conventional wisdom.

Therefore, the present study attempts to examine the causal relationship between domestic saving and economic growth, using Granger causality test. More specifically, the purpose of our paper is to determine whether 
increases in domestic saving Granger-cause GDP growth rate or vice versa. The remainder of the paper proceeds as follows: section 2 covers an overview of domestic saving and economic growth in Cambodia. Section 3 focuses on literature review. In section 4, the data and methodology are discussed. Section 5 presents the empirical results and section 6 provides the summary and conclusion of the study.

\section{An Overview of Domestic Saving and Economic Growth in Cambodia}

The financial sector is considered as a crucial contribution to economic growth across countries through stimulating investment. However, the development of the financial sector is likely to be at different stages across countries. The Cambodian financial sector had passed through many tragic generations, specifically the Pol Pot regime. It was completely destroyed in the regime. In addition, the country's currency, Riel, was also abandoned. After the regime was toppled in 1979, all Cambodian economic sectors were reconstructed with many challenges. From 1979 until 1989, Cambodian financial sector was not seen to progress because the banking industry was not fully motivated due to social upheavals, political instability, and civil wars that still occurred in many parts of the country. However, it was restored fully in the early 1990s after the UN-supervised general election in 1993. Therefore, the Cambodian banking industry and microfinance are likely to progress, but not at a desirable level like those of the neighboring countries. Before the adoption of the Law on Banking and Financial Institutions in November, 1999, Cambodia's gross domestic saving as percentage of GDP was only 1.88\% from 1989 to 1998 on average. This means that saving as a percentage of GDP was very low during this period and was below its potential level as well. This low level of gross domestic saving was due to lack of confidence in the financial sector. However, after the adoption of the Law on Banking and Financial Institutions in November, 1999, the financial sector in the country is likely to progress gradually. It is also seen that gross domestic saving as percentage of GDP seems to rise both constantly and gradually with an average of $11.83 \%$ from 1999 to 2012 . However, for the last seven years from 2005 to 2012, gross domestic saving as percentage of GDP is likely to be relatively high with an average of $14.1 \%$, which indicates that the financial sector in Cambodia seems to grow at a remarkable rate although it is still underdeveloped compared with other member states of ASEAN.

The trend of economic growth in Cambodia has been mixed since 1989. For example, during the period $1989-$ 1998, the average annual percentage growth of GDP in Cambodia was only 4.81\%, with the highest growth rate of about 7.7\% in 1994 shortly after the general election in 1993, but this growth rate of GDP started to decrease gradually to about $5 \%$ in 1998. This slow growth in GDP was mainly attributed to political unrest and external crisis as well as Asian economic crisis in 1997. Cambodia's growth over the period 1999 to 2012 is particularly impressive with the average real output growth of around $8.2 \%$, largely due to the collapse of the Khmer Rouge in 1998, which brings social and political stability to the country. The GDP growth in this period was also due to growth in the four growth-enhancing pillars, namely textile and garment, tourism, construction, and agriculture. Although annual growth rate of GDP was relatively high during the last decade, it seems to be vulnerable to external shocks. For example, in 2009 , the growth rate of output was only $0.1 \%$, which was the lowest rate since 1993. It was mainly due to the financial crisis that occurred in the United States in 2008. This indicates that Cambodian economy seems to be vulnerable to external shocks and the three growth-enhancing pillars, namely textile and garment, construction, and tourism were negatively affected by the crisis. Due to recent economic recovery of the world's largest economies, including the United States, Europe, China, South Korea, and Japan, Cambodian economy seems to gradually regain its economic strength by achieving GDP growth rates of 6\%, $7.1 \%$, and $7.3 \%$ in 2010,2011 , and 2012 , respectively, due to its dependence on these economies.

\section{Literature Review}

There have been many theoretical and empirical studies on the relationship between saving and economic growth. The growth models of Harrod (1939), Domar (1946), and Solow (1956) indicate that increases in saving translate into high investment, which in turn stimulates economic growth. The effect of higher saving increases the availability of funds for investment. The more capital goods a nation has the more goods and services it can produce. This can be said that a higher level of saving rate leads to increased capital stock, which in turn leads to a high level of output. This assumption has also been examined in many empirical studies to determine whether the positive relationship between the variables exists or not. Most studies have been done on the relationship between saving and economic growth in many countries around the globe, but it is not known whether saving plays a major role in promoting growth in Cambodia. To determine the relationship between the two variables, different econometric methods have been used to test whether the conventional wisdom that the causal direction runs from saving to economic growth holds or not.

With the use of Ordinary Least Square (OLS) to determine the impact of saving on economic growth, Jappelli and Pagano (1994) found that higher saving rate leads to higher economic growth. Later, in 2005, Moreira 
examined the impact of foreign aid on economic growth in 42 countries, using GMM for estimation. In the study, domestic saving was also included as one of the determinants of economic growth in the countries under consideration. The empirical results show that domestic saving has significantly positive impact on economic growth. Recently, Tang and Chus (2009) re-examined the saving-growth nexus in Malaysia by using the nonparametric methodology. They have found saving and economic growth to be positively related in the long run. They also confirmed that the policies which encourage saving should be implemented because saving, as indicated in the causality test, is an important driver of economic growth through its impact on investment. Aghion, Comin, Howitt, and Tecu (2009) develop a theory of endogenous local saving and economic growth in an open economy with domestic and foreign investors. Results of the cross-country regression show that lagged savings have positive impact on productivity growth in poor countries, but not in rich countries. In addition, most recent findings on the impact of saving on economic growth in OECD countries by Herzog (2011) indicate that saving rates have significantly positive impact on economic growth.

Aside from OLS and GMM estimation methods, most studies focused on the dynamic relationship of saving and economic growth, using the concept of Granger causality. For example, Sinha (1999) did a study to examine the relationship between the growth rate of saving and economic growth in Sri Lanka. The findings indicate that the causality runs from gross domestic saving to economic growth in this country. Later, in 2005, Romm examined the directions of association between saving and growth in South Africa over the period 1946-1992, using the Johansen VECM estimation technique. The study found the private saving rate to have a direct, as well as, an indirect effect on growth. The author also confirmed that the indirect effect was through the private investment. In addition, the study also found growth to have a positive effect on the private saving. In China, the conventional wisdom that causality runs from saving to economic growth seems to hold. China's economic growth is found to have a long-run relationship with household and enterprise savings. Although this long-run relationship is found, the bi-directional causality is found between domestic saving growth and economic growth only in the short run. In the long run, a unidirectional causality is found to run from domestic saving to economic growth (Lean \& Song, 2009). Recently, Oladipo (2010) employed TYDL methodology to determine the direction of causal relationship between saving and economic growth in Nigeria between 1970 and 2006. Based on the empirical results, saving and economic growth are positively co-integrated, but the study found only a unidirectional causality between saving and economic growth. The findings did not reveal the causal relationship between economic growth and saving.

Although the causal relationship is found to run from saving to economic growth in many studies, others still confirm reverse causality. Carrol and Weil (1994) examined the relationship between income growth and saving, using both cross-country and household data. At the aggregate level, they found economic growth to Granger cause saving, but saving does not Granger cause growth. Using household data, they found that households with predictably higher income growth save more than households with predictably low growth. Based on the findings, they confirmed that previous estimates of the effect of saving on growth may be overstated. In the case of Mexico, Sinha and Sinha (1998) investigated the relationship among private saving, public saving and economic growth, using multivariate Granger causality test. The multivariate causality test shows that there is evidence that the growth of GDP Granger causes the growth of private and public savings. However, they did not find any evidence of reverse causality. Later, in 2008, Sinha and Sinha did another study to examine the relationship between the growth rates of household saving, public saving, corporate saving and economic growth in India, using multivariate Granger causality test. The empirical findings suggest that the causal relationship does not run from saving to economic growth, but they found the opposite direction. This means that in a large economy like India, higher saving does not cause economic growth, but it is the consequence of economic growth. Most recently, Abu (2010) studied the savings-economic growth nexus in Nigeria from 1970 to 2007 using Granger causality and co-integration techniques. The Johansen co-integration test indicates that the two variables are co-integrated, and that a long-run equilibrium exists between them. Based on results of the Granger causality test, the author found causality to run from economic growth to saving, but not from saving to economic growth. This implies that economic growth precedes and granger causes saving.

Aside from single-country studies, some researchers focus on determining the causal relationship between saving and economic growth in many countries at the same time. For instance, Anoruo and Ahmad (2001) examined the causal relationship between saving and economic growth in seven African countries, using cointegration and the vector error correction model (VECM). The results of the cointegration tests suggest that there is a long-run relationship between economic growth and growth rate of saving. The results from the Granger causality tests indicate that contrary to the conventional wisdom, economic growth causes growth rate of domestic saving for most of the countries under consideration. Similar deductions have also been made by Mohan (2006). The author 
examined the relationship between domestic saving and economic growth for various economies with different income levels, by dividing the countries into low-income, low-middle income, upper-middle income and high-income in order to test whether saving plays an important role in influencing the direction of causality. The results suggested that in low-income countries, the results are mixed, but causality runs from economic growth to growth of saving in lower-middle income countries. In upper-middle income countries, the results reveal bi-directional causality, but in high-income countries, except Singapore, the causality is from economic growth to growth of saving. The study concludes that the income class of a country plays an important role in determining the direction of causality. Misztal (2011) who examined the causal relationship between saving and economic growth in both developed and developing countries. The author did not find enough evidence to show that the causal direction runs from saving to economic growth in the countries under consideration. Most recently, Ijeoma, Paramaiah, and Moshoeshoe (2011) examined the causal relationships between financial development, saving, and economic growth in Lethoso. They found that saving and economic growth are independent of each other in this country. So it can be said that saving and economic growth are independent of each other.

Theoretically, the conventional wisdom confirms that the causal direction runs from saving to economic growth, but many empirical findings indicate that this conventional wisdom does not hold. Different studies provide different findings. This means that findings on the causal relationship between saving and economic growth are still inconclusive. This may be due to the quality of data or the estimation techniques that were used.

\section{Data Description and Methodology}

The data employed in this analysis are annual and taken from Asian Development Bank's Key Indicators for Asia and the Pacific (2013) and UNCTAD (2013). Economic growth is annual real GDP growth rates, covering the period 1989-2012. The data for this variable is received from UNCTAD (2013). Saving is the ratio of gross domestic saving to GDP, covering the same period. The data is received from ADB (2013). Selecting the data for the two variables from different sources is due to lack of data for all years from each source. Despite data constraints, the study has made sure that the two data sources can be reliable because most economic data are published yearly by the two institutions for many countries around the world. In addition, many empirical studies use data from the two sources as well.

\subsection{Model Specification}

The directions of causality between two variables cannot be told through regression analysis. In this regard, the causality estimating technique, Granger causality test developed by Granger in 1969, is employed in order to determine the causal relationship between domestic saving and economic growth and vice versa. Understanding the causal direction between saving and economic growth is very beneficial for both researchers in economics and policy makers to know whether saving plays a major role in explaining economic growth. The results from test help us to know the causal directions between the two variables. The Granger causality test (Granger, 1969) regresses a variable $Y$ on a lagged value of itself and another variable $X$. If $X$ is significant, it means that it explains some of the variance of $Y$ that is not explained by lagged value of $Y$ itself. This indicates that $X$ is causally prior to $Y$ and said to Granger cause $Y$. Accordingly the model can be specified as follows:

$$
Y_{t}=\sum_{i=1}^{n} \alpha_{i} Y_{t-i}+\sum_{i=1}^{n} \beta_{i} X_{t-i}+e_{t}
$$

However, selecting the lead/lag length is not a simple task, specifically when the number of observations is relatively small. In estimating the causal relationship between two variables with the use of Granger causality test, all the data series must be stationary. In case that the data series are non-stationary, first difference must be taken to detrend the data. Therefore, Equation (1) is then rewritten as:

$$
\Delta G D P_{t}=\sum_{i=1}^{n} \alpha_{i} \Delta G D P_{t-i}+\sum_{i=1}^{n} \beta_{i} \Delta(\text { Saving })_{t-i}+e_{t}
$$

And

$$
\Delta(\text { Saving })_{t}=\sum_{i=1}^{n} \gamma_{i} \Delta(\text { Saving })_{t-i}+\sum_{i=1}^{n} \theta_{i} \Delta G D P_{t-i}+u_{t}
$$

Where $\Delta$ is the first difference operator; GDP is annual real GDP growth rates; saving is the ratio of domestic saving to GDP; $n$ is the maximum lag length; $t$ is a time trend; and $u$ is a stationary random error. In order for the causal relationship between the two variables to exist, the estimated coefficients on lagged Saving in Equation (2) and on lagged GDP in Equation (3) should be significantly different from zero. So this means that $\beta$ and $\theta$ should be significantly different from zero $(\beta \neq 0$ and $\theta \neq 0)$. In this case, simultaneous causality is said to exist. On the contrary, if the estimated coefficients of the two variables are not significantly different from zero, GDP and Saving are said to be independent of each other. It means that they do not have a causal relationship. 


\subsection{Unit Root Test}

Very few time series data are stationary, but many are found to be nonstationary. Based on this, it cannot be concluded that all series have a unit root and that all are stationary (Karlsson \& Löthgren, 2000). If any time series data is nonstationary, the mean of that series is time-dependent (Pindyck \& Rubinfeld, 1998, p. 497). The series should be first-differenced, so the resulting series will be stationary. Before carrying out Granger causality test, the stationarity test for the data series must be done by conducting an augmented Dickey-Fuller test (Dickey \& Fuller, 1979), which involves estimating the following regression:

$$
\Delta X_{t}=\alpha+\rho t+\beta X_{t-1}+\sum_{i=1}^{n} \gamma_{i} \Delta X_{t-i}+\varepsilon_{t}
$$

In the above equation, $X$ is the variable under consideration; $\Delta$ is the first difference operator; $t$ is a time trend; and $\varepsilon$ is a stationary random error. If the null hypothesis that $\beta=0$ is not rejected, it is known that the variable series contain a unit root and is non-stationary. The optimal lag length is also determined in the ADF regression and is selected using the Schwarz Information Criterion (SIC).

\section{Empirical Results and Discussion}

In this section, the empirical results for the paper are presented and discussed. Firstly, the results for the unit root test are presented. The second part shows the results of the Granger causality test to examine the causal relationship between domestic saving and economic growth.

\subsection{Unit Root Test Result}

Before starting the analysis, it is important to study the unit root properties of the data. We use the Augmented Dickey-Fuller (ADF) test, which is widely-used to determine the stationarity of time series data (Dickey \& Fuller, 1979). The results of the unit root test for variables in their level and first difference are presented in Table 1. The data series for GDP is found to be stationary at level, but the data series for domestic saving is non-stationary at level. If this non-stationary data series is used to perform the Granger causality test, the results of the test may be spurious (Abeysinghe, 1994). In order to make it stationary, the same test must be performed on first difference for this variable. After taking first difference, saving is found to be stationary. Based on the results of ADF test in Table 1, GDP growth rate is found to be stationary at level, but saving is stationary at first difference.

\subsection{Granger Causality Test Result}

Long run growth theories imply that economic growth is positively influenced by investment, meaning that a higher level of investment may lead to higher economic growth. However, the level of investment is influenced by many factors, most importantly as confirmed in the neoclassical growth theories, saving. When saving increases, more funds for capital investment will be available, leading to higher investment. Empirically, the causal relationship between saving and growth is not found to exist in many countries. Some findings confirm the existence of a causal relationship between saving and economic growth, some confirm a reverse causality, but some indicate a bi-directional causality between the two variables. Therefore, it can be said that findings on the causal relationship between saving and economic growth are still inconclusive. Results of the present study confirm the coefficient of causality between saving and economic growth in Cambodia to be insignificant $(p>$ 0.05), meaning that the causal direction does not run from saving to economic growth in this country (See Table 2). So saving does not Granger cause economic growth in Cambodia. This finding is contrary to the conventional wisdom that economic growth is the cause of saving (Solow, 1956), but it is in line with the result found by Misztal (2011) who examined the causal relationship between saving and economic growth in both developed and developing countries. The author did not find enough evidence to show that the causal direction runs from saving to economic growth in the countries under consideration. The finding is also consistent with other studies carried out by Sinha and Sinha (2008), Abu (2010), and Carrol and Weil (1994) who found that saving does not Granger cause economic growth.

The present study does not find causality to run from economic growth to saving in Cambodia as well. This implies that economic growth does not Granger cause saving because the coefficient is not significant $(p>0.05)$ (See Table 2). This finding is consistent with a number of studies done by Tang and chua (2009), and Ijeoma, Paramaiah, and Moshoeshoe (2011) who found that economic growth does not Granger cause saving. Most importantly, Ijeoma, Paramaiah, and Moshoeshoe (2011) examined the causal relationships between financial development, saving, and economic growth in Lethoso. They found saving and economic growth to be independent of each other in the country under consideration. 
Table 1. Augmented Dickey-Fuller (ADF) test

\begin{tabular}{llll}
\hline Variable & ADF - statistic & Critical value & Order of integration \\
\hline GDP & $-3.299410 *(0)$ & -2.998064 & Stationary at level \\
$\Delta$ Saving & $-6.060643 * *(0)$ & -3.769597 & Stationary at first difference \\
\hline
\end{tabular}

Note. Significance levels are $* 5 \%$ and $* * 10 \%$. $\Delta$ stands for first difference. Lags in parentheses are determined using Schwarz Information Criterion (SIC). The critical values for the two variables are without trends at level and at first difference.

Table 2. Pairwise Granger Causality test

\begin{tabular}{llcc}
\hline Null Hypothesis: & Observation & F-Statistic $\left.{ }^{*}\right)$ & P-value \\
\hline$\Delta$ Saving does not Granger Cause GDP & 22 & 1.54174 & 0.2295 \\
GDP does not Granger Cause $\Delta$ Saving & & 0.16129 & 0.6925
\end{tabular}

Note. $\Delta$ stands for first difference. * Indicates the number of lags which was determined by using the Schwarz Information Criterion (SIC).

\section{Conclusion}

Although many theoretical and empirical studies confirm the positive impact of saving on economic growth, results of the present study show that there is not enough evidence to confirm that saving Granger causes the growth of GDP in Cambodia. The study also does not find any evidence of reverse causality. For the case of Cambodia, saving does not seem to play a major role in contributing to economic growth; it may be due to some other reasons that cause saving to be unproductive to growth or there may be some other factors that contribute to economic growth in this country instead of saving. This implies that the conventional wisdom that higher level of saving leads to economic growth is not likely to hold in Cambodia. In addition, economic growth is also not found to Granger cause saving. It may be because the level of real GDP per capita is so small in this country; therefore, it cannot be an important source of saving. This indicates that economic growth in Cambodia may be the cause of other variables other than saving. Based on the findings, domestic saving and economic growth are concluded to be independent of each other in Cambodia. Further studies should be conducted with special focus on the main drivers of economic growth in this country.

\section{References}

Abeysinghe, T. (1994). Deterministic seasonal models and spurious regressions. Journal of Econometrics, 61, 559-572.

Abu, N. (2010). Saving-economic growth nexus in Nigeria, 1970-2007: Granger causality and co-integration analyses, Review of Economic and Business Studies, 3(1), 93-104.

Aghion, P., Comin, D., Howitt, P., \& Tecu, I. (2009). When does domestic saving matter for economic growth? Working Paper 09-080, Harvard Business School.

Anoruo, E., \& Ahmad, Y. (2001). Causal relationship between domestic savings and economic growth: Evidence from seven African countries. African Development Review, 13(2), 238-249.

Asian Development Bank. (2003). Key Indicators for Asia and Pacific. ADB.

Carroll, C., \& Weil, D. (1994). Saving behavior in ten developing countries. Carnegie-Rochester Conference Series on Public Policy, 40, North-Holland, Amsterdam.

Dickey, D. A., \& Fuller, W. A. (1979). Distribution of estimates of autoregressive time series with unit root. Journal of the American Statistical Association, 427-431.

Domar, E. D. (1946). Capital expansion, rate of growth, and employment. Econometrica, 14, 137-147.

Granger, C. W. J. (1969). Investigating causal relations by econometric models and cross spectral methods. Econometrica, 37, 424-438.

Harrod, R. (1939). An essay in dynamic theory. Economic Journal, 49, 14-33.

Herzog, R. W. (2011). Saving, growth, and age dependency for OECD countries, MPRA Paper No. 32055. Retrieved from http://mpra.ub.uni-muenchen.de/32055/

Ijeoma, O., Paramaiah, C., \& Moshoeshoe, R. E. (2011). Financial development, savings and economic growth in Lesotho : evidence from trivariate causality tet. International Journal of Economics and Business Studies, 1, 
$41-55$

Jappelli, T., \& Pagano, M. (1994). Savings, growth and liquidity constraints. Quarterly Journal of Economics, 109, 83-109.

Karlsson, S., \& Lothgren, M. (2000). On the power and interpretation of panel unit root tests. Economics Letters, $66,249-255$.

Lean, H. H., \& Song, Y. (2009). The domestic savings and economic growth relationship in China. Journal of Chinese Economic and Foreign Trade Studies, 2(1), 5-17.

Misztal, P. (2011). The relationship between savings and economic growth in countries with different level of economic development. Financial Internet Quarterly, 7(2), 17-29.

Mohan, R. (2006). Causal relationship between savings and economic growth in countries with different income levels. Economics Bulletin, 5(3), 1-12.

Moreira, S. B. (2005). Evaluating the impact of foreign aid on economic growth: A cross-country study. Journal of Economic Development, 30(2), 25-48.

Oladipo, O. S. (2010). Does saving really matter for growth in developing countries? The case of a small open economy. International Business \& Economics Research Journal, 9(4), 87-94.

Otani, I., \& Villanueva, D. (1990). Long-term growth in developing countries and its determinants: An empirical analysis. World Development, 18, 769-783.

Pindyck, R. S., \& Rubinfeld, D. L. (1998). Econometric Models and Economic Forecasts (4th ed.). US: Irwin/ McGraw-Hill.

Romm, A. T. (2005). The relationship between savings and growth in Africa: A time series analysis. South African Journal of Economics, 73(2), 171-189.

Sinha, D., \& Sinha, T. (1998). Cart before the horse? The saving-growth nexus in Mexico. Economics Letters, 61, 43-47.

Sinha, D. (1999). Saving and Economic Growth in Sri Lanka. Indian Journal of Applied Economics, 8(3), 163174.

Sinha, D., \& Sinha, T. (2008). Relationships among household saving, public saving, corporate saving and economic growth in India. Journal of International Development, 20, 181-186. http://dx.doi.org/10.1002/jid

Solow, R. M. (1956). A contribution to the theory of economic growth. Quarterly Journal of Economics, 70, 6594.

Tang, C. F., \& Chau, S. Y. (2009). The savings-growth nexus in Malaysia: Evidence from nonparametric analysis. The IUP Journal of Financial Economics, 7(3\&4), 83-94. http://dx.doi.org/10.1080/00036846.2011.587784

\section{Notes}

Note 1. The Pol Pot regime is known as the genocidal regime, which occurred from 1975 to early 1979 in Cambodia. Almost all types of infrastructure and approximately two million lives had been devastated in the regime.

Note 2. It is the first general election that was conducted in Cambodia since the collapse of the Pol Pot regime and the economic reform from a planned economy to a market economy in Cambodia. The election was supervised by the United Nations in 1993. All fighting factions participated in the election, except the Khmer Rouge. 


\section{Appendix A.}

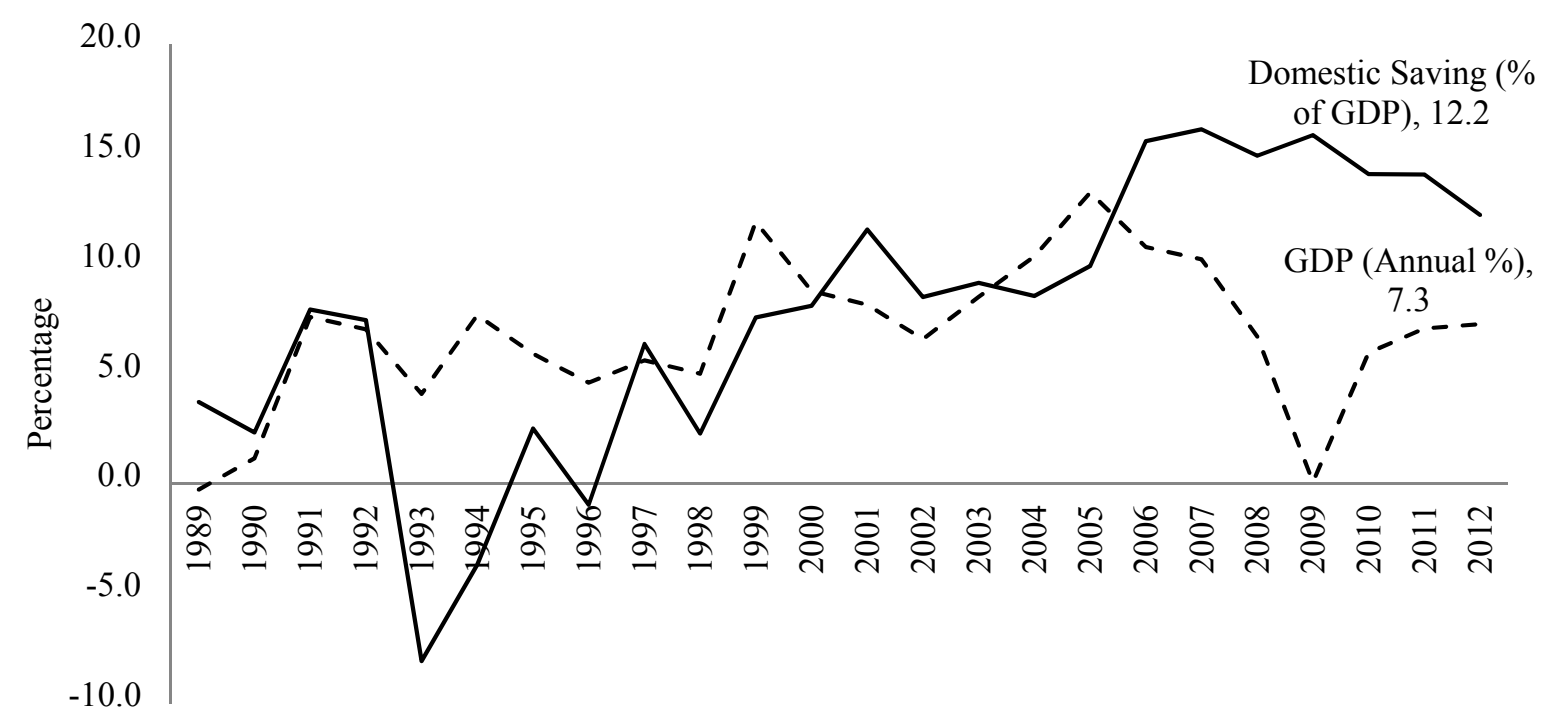

Figure A1. The trends of gross domestic saving and GDP growth rate in Cambodia

\section{Copyrights}

Copyright for this article is retained by the author(s), with first publication rights granted to the journal.

This is an open-access article distributed under the terms and conditions of the Creative Commons Attribution license (http://creativecommons.org/licenses/by/3.0/). 